\title{
Construction and Research of Port Seaborne Transportation System
}

\author{
Bi Yanliang \\ Binzhou Polytechnic, Ocean, Department, Binzhou Shandong 256603, China
}

Keywords: Fujian Province; container; sea-rail combined transport; port

Abstract: This paper starts with the status quo of port container development in Fujian Province, expounds the problems existing in the development of port container sea-rail combined transport in Fujian Province, analyzes the significance of developing container sea-rail combined transport, and finally proposes that the port of Fujian Province accelerates the container sea. Several suggestions for the development of rail transport.

\section{Introduction}

In recent years, Fujian Province has focused on promoting the construction of "two episodes and two scattered" ports, focusing on accelerating the construction of large-scale deep-water wharfs and deep-water navigation channels in the "two episodes and two scattered" port areas of Xiamen Port, Fuzhou Port, Luoyuan Bay and Meizhou Bay, and improving the port. The level of intensification will enable the port to form a scale as soon as possible and enhance its competitiveness. In particular, Xiamen Port's container transportation has developed rapidly, and container throughput has grown rapidly. It has become one of China's important ports and the "leading” port of Fujian Province.

\section{Problems in the development of container sea-rail combined transport}

\subsection{Container sea-rail combined transport system is not perfect}

The highways and water routes in Fujian Province are in charge of the Transportation Department of Fujian Province. The railways are directly managed by the Ministry of Railways. The international container transportation also involves customs, inspection and quarantine and other regulatory departments and financial institutions. These parallel government departments are in charge of management regulations and management methods. The practices and characteristics of management tools and system operations are significantly different. For a long time, transportation capacity and transportation speed are insufficient. In particular, the "bottleneck" on the main transportation channels has made Fujian Province develop in the field of container transportation. The willingness to develop is slow. Therefore, the coordination and management issues between various departments should be resolved as soon as possible. Fujian Province can change the pattern of this unsound operation system of container sea-rail combined transport. The container sea-rail combined transport in Fujian Province can develop in a healthy and sustainable manner[1]. 


\subsection{Intermodal information exchange is not smooth}

Sea-rail combined transport is different from single transport. Sea-rail combined transport increases the number of transport links and information exchange, and the complexity of operations increases much more than single transport. At present, Fujian Province has not realized the electronic data interchange (EDI) of roads, ports, ships and goods.

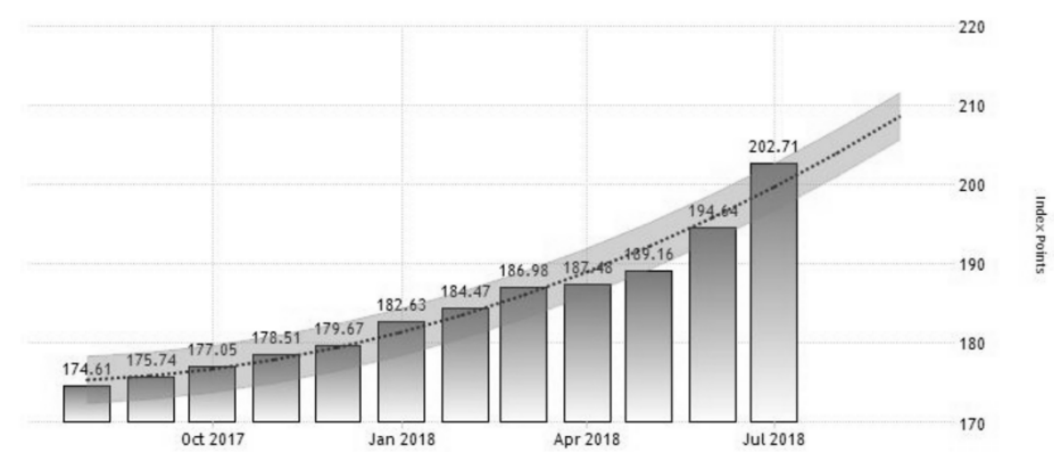

Figure 1: Fujian port transportation speed growth.

\subsection{Low level of railway container transport services}

The complicated handling procedures of the railway, opaque container information services, irregular charging items, and unfulfilled transportation commitments have reduced the level of railway transportation services, making container users reluctant to deliver containers to the railway department for transportation. For the railway sector, the key issue in increasing the proportion of container shipping.

\section{Significance of developing container sea-rail combined transport}

3.1. Container sea-rail combined transport is an important guarantee for expanding the hinterland of the port

China's coastal high-quality coastline resources are numerous, and the port distribution is also very dense, resulting in the narrow hinterland of coastal ports, and the competition for expansion in the hinterland between ports is also intensifying. With the development of China's economy and the implementation of the strategy of "developing the city with Hong Kong and developing the port with Hong Kong”, the port of Fujian Province must keep pace with the planning of the country and must be at the forefront of the development of the port. The port of Fujian Province should pay attention to it. The expansion of the hinterland of the port has increased cooperation with the railway, built developed hardware facilities, and integrated the intermodal transport of sea-rail combined transport into the inland. By improving the level of railway container transport services, the development of the export-oriented economy in the inland areas will be promoted. The demand for containers in the land area has increased, and the radiation range of the port has been further expanded[4].

\subsection{Container sea-rail combined transport is an important means to achieve energy saving and emission reduction in the transportation industry}

Under the premise of fulfilling the same transportation demand, we should make use of the transportation mode or organization mode with low transportation cost, relatively low energy 
consumption and relatively small environmental impact, and improve the efficiency of energy conservation and emission reduction through the improvement of transportation organization structure, which is undoubtedly realized by the transportation industry. The fundamental path of sustainable development. According to calculations, the fuel consumption per kilometer of railway container transportation is less than half of that of highway container transportation. Therefore, vigorously developing container sea-rail combined transportation is one of the most important means for energy conservation and emission reduction in the transportation industry, and one of the most effective means. . Accelerating the construction of a developed railway network and actively developing fast passenger dedicated lines and double-deck container trains are becoming major measures to promote energy conservation and emission reduction in China's transportation sector.

\subsection{Container sea-rail combined transport is an important way for enterprise development}

With the acceleration of the process of economic globalization, more enterprises are facing international competition. The space for enterprises to obtain profits from traditional production links and sales links is getting smaller and smaller. The fast, low-loss, zero-inventory of circulation links has become a corporate search. A new source of profit growth, companies have sought ways to achieve high levels of transportation and sufficient transportation capacity in order to achieve more lucrative profits.

\section{Measures and Suggestions for Accelerating the Development of Container Sea-rail Combined Transport}

\subsection{Strengthening cooperation between ports and railways}

Fujian ports should strengthen cooperation with railways, jointly build container handling stations, speed up the construction of railways in port areas, extend railways to port loading and unloading areas, and achieve effective connection between MTR and rail transport. At the same time, the construction of container reloading stations, the opening of container trains, speeding up the turnover of containers, and providing "door to door" services. Further optimize and integrate the port stations and railways in the port to realize the direct loading and unloading of ships and trains, and the seamless connection of railway trains to and from straight lines in the port, that is, to construct a new "transport-rail train" mode. In this way, the port yard area is saved, the yard construction investment and land development costs are reduced, the intermediate links are reduced.

\subsection{Strengthen the construction of transport corridors and improve the port collection and distribution system}

The passage is a bridge between the port and the hinterland, and it is the link between the city and the hinterland. The construction of the passage determines the depth and breadth of the interaction between the port and the hinterland. Therefore, it is necessary to increase the construction of horizontal collection and distribution channels leading to the hinterland of the inland, and speed up the construction of the port corridors connecting the major port areas. On the basis of the existing access to the provincial passages of Yingxia, Waifu, Hengnan, Meikan, Longxia and Xiaolong, accelerate the construction of horizontal railways such as Xiangyu and Ninglang, improve the backbone of the railway network, and improve the grade of the road network. And the ability to operate, to increase the density of the horizontal trunk roads of Beijing-Kowloon and Beijing-wide arteries. Through the double-track and electrification construction, the Longxia and Xiaolong railways will be built into the main roads with great capacity and high speed. 


\subsection{Strengthening alliances in provincial ports to improve port competitiveness}

Due to the development of maritime transport and the huge changes in the hinterland of the port, the competition in the port has accelerated, especially in the most dynamic East Asia region of the world economy. However, the Port Port of Fujian Province has been engaged for many years, and it is still a group disagreement. It is still driven by local interests and engages in fratricidalism, which hinders the development of Fujian's economy and ports. Fujian Province must grasp the development trend of international transportation, correctly position the port, and formulate corresponding investment policies, especially pay attention to cultivating, fostering and developing key ports with favorable conditions.

\section{Conclusions}

It is recommended that the relevant departments formulate specific preferential policies for the sea-rail combined transport of the Xiangyu Railway, and put forward corresponding requirements for port services, customs declaration, inspection, commodity inspection, customs clearance, etc., so that Jiangxi's bulk supply can be turned in time after the opening of the line.

\section{References}

[1] Yi Zhang, Chul-Woo Kim, Kong Fah Tee, Jasmine Siu Lee Lam. Optimal sustainable life cycle maintenance strategies for port infrastructures[J]. Journal of Cleaner Production,2017,142.

[2] Ziaul Haque Munim, Hercules Haralambides. Competition and cooperation for intermodal container transhipment: A network optimization approach[J]. Research in Transportation Business \&amp; Management,2018,26.

[3] Yi Zhang, Jasmine Siu Lee Lam. Estimating economic losses of industry clusters due to port disruptions[J]. Transportation Research Part A,2016,91.

[4] Yi Zhang, Chul-Woo Kim, Kong Fah Tee, Jasmine Siu Lee Lam. Optimal sustainable life cycle maintenance strategies for port infrastructures[J]. Journal of Cleaner Production,2017,142. 